\title{
Study on the Pension Rights of Families That Have Lost Their Only Child
}

\author{
Xiaoyang Zhang \\ Political Science and Law School, Northeast Normal University, Jilin, China \\ Email: 378356587@qq.com
}

Received 26 December 2014; accepted 14 February 2015; published 17 February 2015

Copyright (C) 2015 by author and Scientific Research Publishing Inc.

This work is licensed under the Creative Commons Attribution International License (CC BY). http://creativecommons.org/licenses/by/4.0/

\begin{abstract}
According to incomplete statistics, the number of families that have lost their only child had reached more than one million in China currently, following an annual increase by 76,000 . The problem of elder care of these families that have lost their only child has become a hot issue in China. Legislation and relevant policies about families that have lost their only child are not sufficient, which have caused the lack of basis on establishing a reasonable elder care system of those families. This paper is aiming to address the rights as a core and further supplement on the basis of the present situation of families that have lost their only child, therefore implement to build the pension right system of loss of only child families. Meanwhile, we also strive to put forward specific advices on establishing legislation and relevant policies.
\end{abstract}

\section{Keywords}

Pension Rights, Families That Have Lost Their Only Child, Elder Care

\section{Introduction}

China has been implementing a nationwide family planning policy since 1973 . The majority of couples at reproductive age responded to the call and only gave birth to one baby. However, more than one million children or young adults have died before the age of 25 from 1975 to 2010, which leaving more than two million parents. Those parents had become childless elders later. According to incomplete statistics, the number of families that have lost their only child has reached more than one million in China, following an annual increase by 76,000. The problem of elder care of these families that have lost their only child has become a hot issue in China.

National Population and Family Planning Commission said that they would adhere to the basic policy of family planning unswervingly and would improve the policy gradually; at the same time, they would address this practical problem of family planning. In 2007, about 10 pilot assistance systems of families that have lost their 
only child have been carried out across some provinces and cities and to the whole country gradually. At the end of 2007, China's Ministry of Finance with National Population and Family Planning Commission jointly issued the Special Assistance System for the Family Planning. Under this policy, woman at least 49 years old, who had lost their only child, would get no less than 100 Yuan each month. Currently, the local governments carry out this policy in different way. For example, in Beijing, Chongqing, Guangdong, Fujian, Shanxi, and Gansu, each woman can get more from 200 to 1600 Yuan per month.

The Information Office of the State Council of China held the press conference on the progress of the livelihood security since the 16th National People's Congress of Communist Party of China on February 15, 2013. Dou Yupei, Deputy Minister of the Ministry of Civil Affairs, said, "We have noticed these problems, and we can refer to the policy on the three-no elders to solve some of the problems in future." With regard to elder care of families that have lost their only children, three-no elders were referred to the group who have "no ability to work, no source of income, and no legal entitlement to elder support". The support for three-no elders is funded by the government now. The issue raised by families that have lost their only child is a new problem after the implementation of China's family planning, and is a different problem from three-no elders issue. Therefore, whether the solution of three-no elders can be applied to it needs further discussions. Legislation and relevant policies about families that have lost their only child are not sufficient, which have caused the lack of basis on establishing a reasonable elder care system of those families. This paper is aiming to address the rights as a core and further supplement on the basis of the present situation of families that have lost their only child, therefore implement to build the pension right system of loss of only child families. Meanwhile, we also strive to put forward specific advices on establishing legislation and relevant policies.

This article is divided into six sections. The introduction sketches the background, the issue, and the significance of this study. In the Section 2, this article explains why the pension rights of families that have lost their only child are inadequate. In the Section 3, the legitimacy on the protection of pension rights of families that have lost their only child in China has been emphasized. In the Section 4, the principles of the pension rights of loss of only-child families have been built. In the Section 5, we talk about how to structure the construction of elder care system of families that have lost their only children. In the Section 6, this article concludes by supporting the establishment of a perfect system.

\section{The Pension Rights in Elder Care of Families That Have Lost Their Only Child Are Inadequate}

The pension rights in elder care are the rights which people can get material support from country and society when they reach an older age. The lack of pension rights in elder care of families that have lost their only child is list below.

\subsection{Families That Have Lost Their Only Child Lost Family Elder Care and Support}

The function of family support is essential and widely. Families that act as the direct space for survival and the basic social organization for development play an important role in personal growth and social life. Tendering the elders is also how humans can pass on with generations. This includes financial support, emotional communication and daily assistance between the family members. With the development of social division of labor, the function of raising children and supporting the elderly becomes socialized. However, the elder care function of family is still the main way to support the elderly (Yang et al., 2011: p. 22). In the one-child family, the function of the child to bridge and support the family is more and more prominent. The function of family is divided into two major aspects, survival and development, which are embodied in reproductive function, tending and elder care function, economic function, educational and social functions, emotional communication capabilities, rest and entertainment functions and so on. Losing the only child broke those basic functions in families that have lost their only child, especially in elder care function. The elder care in China today is mainly based on elder care from family; families that have lost their only child had lost elder care function. Families that have lost their only child are not just a group that lost children; they had also lost the generation, the spiritual sustenance, the source of life and the basic old-age security.

\subsection{The Insufficiency of the Institutions Specialized in Elder Care}

There are no institutions are established exclusively for elder care of families that have lost their only child in 
China. The existing elder care institutions cannot provide service for families that have lost their only child. The institutions for elder care in China can be divided into welfare institutions and profitable institutions, while the welfare institutions for elder care in China only accept three-no elders. The profitable institutions are reluctant to accept them since they can't meet certain requirements such as the guarantee from their children who should sign the agreement when they check in. Therefore, there are no suitable institutions for elder care of families that have lost their only child. In summary, it is practically hard to take care of childless elders in institutions way without the special institutions in China now.

\subsection{Benefits of Families That Have Lost Their Only Child Are Hard to Express and Realize}

Lack of relevant legal and policy support, families that have lost their only child has no managing department or mechanism which can realize their rights. Article 27 of 2001 Population and Family Planning Law of the People's Republic of China clearly stipulate: "For those children who are disabled or diseased in accident, if their parents are no longer procreate or adopt children, local governments shall provide necessary assistance". However, there is no definition of "necessary assistance", nor did it stipulate which department performs on the implementations, and how to implement weren't mentioned in the law. Other relevant laws, such as the Law about Protection of the Rights and Interests of the Elderly, Marriage Law, the Law about Population and Family Planning, none of these laws could clearly stipulate the issue about the pension of families that have lost their only child. Caused by the lack of legislation, benefits of the express mechanism and realizing the rights of such families has remained as borderline http://fanyi.baidu.com/ and needs to be strived for their social security. Their situation also have become awkward and difficult. Families that have lost their only child can't appeal their interests and this has lead to the absence of right.

\subsection{Having No Labor Force in Country Side Has Lead to Difficult Position for Elder Care}

In rural area of China, the opinion of raising children for old age is more than a concept. With the first group of peasant couples who have been complied with the family planning are becoming older, the families lack of labor force. So how to provide for their senior care had become a relative and urgent problem. However, some prominent problems that the families of abiding by the family planning faced have affected enthusiasm and initiative for some rural families to carry out family planning.

\section{The Legitimacy on the Protection of Pension Rights of Families That Have Lost Their Only Child in China}

\subsection{The Necessity of Protecting the Vulnerable Groups for Social Contract}

\subsubsection{Social Contract Is the Philosophical Foundation of the Protection of Vulnerable Groups}

Social contract is considered an agreement that we should govern society by the law. We can use the agreement to establish social benefit distribution, to protect the weak and then make a reasonable liberal and equal society. During this process, it must refer to transfer of right, so every citizen can receive equal treatment, enjoy equal right if they transfer their right. The equality what we say is the substantial equality, which means every citizen can receive true equality. In this sense, the social contract's substance is the philosophical foundation of strengthening society governance, putting finance into practice for benefiting the people and protecting the weak. Social contract's moral ideal is to find the gist and contract governance pattern for citizen, society and state, to balance their conflicts of benefit, to solve the tension between liberty and equality, the exclusion between the strong and the weak (Zhao et al., 2011: p. 3).

\subsubsection{The Reciprocity of Social Contract Is the Requirements of Justice for Fair Social Relationships}

The social contract is widely regarded as the reciprocal contract that all rights will come true by transferring some right. This reciprocal benefit exchange reflects social relationships' fairness. However, the process of concluding the social contract would put them at a competitive disadvantage for vulnerable groups, neither these people's essential requirements nor their requirements of existence and development would not be realized and satisfied. Therefore, our government should intervene it, proceed from protecting vulnerable groups' essential existence and dignity, make the distribution justice of rights and benefit come true and protect vulnerable groups' 
existence and development right. In China, families that have lost their only child have its particularity, which is resulted from policies. They responded to the state's appeal about family planning and complied with public benefit. In this sense, the government should give more care to "families that have lost their only child" which is also the requirement of social justice.

\subsection{Consistency of Government's Power and Duties}

The power and duties of government should be coincident. It is a certain description for the relationship of government's power and duties and the public benefit is considered the value orientation of this consistency. The government's power is not only public but also expansionary for the public benefit protection and this expansionary could lead to impossibility for individual benefit's realization. On this thesis, the government relies on its administrative power to implement the family planning and one-child policy, therefore the government should be responsible for the adverse consequences on individual, especially for the vulnerable groups which is called "families that have lost their only children". The government should bear the corresponding responsibility to protect their rights and benefit such as medical treatment and pension. Mu Guangdong, the professor of Institute of Population Research, Beijing University said, "If the family bereaving of only child belongs to one-child policy risk family, using the government's power to solve their problems that includes difficult to care, difficult to go to a doctor, difficult to rely on, difficult to have a happy elder year will be completely reasonable" (China Youth Daily, 2013). Consistency manifestation of government's power and duties is various, which can reflect in government, organization and individual, for example, between government and individual, government should protect people's right and welfare. "Both material benefits and spiritual interests of the childless groups are injured seriously because of the only child's death. The essential reason for the damage is the public policy which stands for the government's power, so we should give special protection to this special group” (Liu, 2011: pp. 27-29). Therefore, around childless group's realization of the right and welfare, the government should manage, preserve and develop social public utilities, and protect childless elders who are in plight.

\section{The Principles of Protecting Pension Rights for Loss of Only-Child Families}

\subsection{The Principle of Taking Rescue Respectively and Diversified}

We should take personality right as the core content for rescue, and the property rights which include the right to life and health, personal equality, mental benefits next to it. Meanwhile, we should take rescue respectively and differently between town families and country families according to China's actual situation. The main measures are to strengthen the practical ability raise, psychology, health and employment supporting in city, but we should improve the people ability to survive in the rural area.

\subsection{The Principle of Government's Dominating Responsibility}

From the perspective of legal rights, human rights will be written into the law, especially in the constitution. The pension rights in the constitution are on the basis of citizenship which is the social rights affirmatively and positively. With the constitution addresses the right of life when people retire and the right of material help from country and society on the condition of old age, disease or lose labor ability. The government should take positive actions to perform the obligations to protect the elderly (Liu, 2008: p. 58). We should emphasize the dominated responsibility of the government in building an elder care system for families that have lost their only child. As the manager of social affairs by law, the government should take dominated responsibility in the aspect of the elimination of poverty, ease conflicts, maintain social stability and promote the social well-being, which aim at establishing a sound social assistance system. The government should also provide social assistance funds and strengthen management and oversight of the use of funds, etc.

\subsection{The Principle of Subjectivity}

Study the social contract theory, we can find that the responsibility to protect vulnerable groups of the government is a behavior on the basis of personal freedom, which embodies the principle of subjectivity. The principle of subjectivity means the individuals have the right to dispose of its own interests, to decide their own behavior from the national mandatory and the government compulsory. The theory builds on the basis of natural law, that 
is, people have gifted natural rights, freedom and equality. Everyone has their own personal ownership, by which one can dominate himself as long as meet each other's self ownership. From the proposition that everyone has self control that is a kind of freedom, by which contract theory introduced another proposition, that is natural rights of freedom means a kind of equality of nature. If everyone has the right of freedom for life, then any others have the same rights. Therefore, no one born should obey the political control of others. The concept of natural freedom is the core of the consent-theory (Will, 2005: pp. 389-392).

\subsection{The Principle of Humanitarian}

Concerning for people especially the people in plight and the care for humanity is an important sign of social progress. The way of traditional rule is the authority of paternalism which is above the individual, emphasis on the common interests of the whole society. Sometimes the rule denies the legitimacy of individual interests, inhibits or rejects organized to express individual interests. The governance which is single and lack of diversity is unable to adapt to modern society. The government should adhere to the principle of humanitarian to do with the pension rights of loss of only-child families. It should pay attention and focus on the construction of social welfare system and fair policy, provide assistance to the poor who are unfortunate or getting into misery, establish a mechanism of humane care to the disadvantaged to protect human dignity and equality of personality and realize the happiness of human at the end.

\section{The Construction of Elder Care System of Families That Have Lost Their Only Children}

The full concept of elder care includes economic support, life care and emotional support. We're going to discuss the specific path of how to protect the group of families that have lost their only children's right from the perspective of rights.

\subsection{Define the Right Subject Accurately}

On the issue of right protection of families that have lost their only children, there are lots of defects in China's legal system, like as internal consistency, the feasibility of the law and Practical utility. First of all, we must accurate the concepts of families that have lost their only children and childless elders, define the range of elder care rescue. According to The National Pilot Assistance System of Families That Have Lost Their Only Children which was published on 31st Aug 2007, only families that have lost their only children (people who didn't give birth or adopt another child after the only children dead) in rural area or in city should get family support, thus, people who should enjoy the elder care right must be permanent families that have lost their only children, it means people who neither loss birth given condition temporarily nor adopt children. The families that have lost their only children but the mother is still young either has well body condition which can give another birth are not in the support range. From the point of view of rights and interests protection, we are going to protect the families that have lost their only children temporarily to get the rights bearing another children by using policy and laws, rather than elder care rights.

\subsection{Expand the Right of Social Relief of Childless Elders}

The right of social relief is considered to be the basic human rights of modern civilized society, and is constitutional rights. To realize social relief right is the core content of elder care system of families that have lost their only child. There is no specific provision in the law of our country about the social relief right. The 22nd article of The Universal Declaration of Human Rights says that, every people, as a member of society, has the right to get social security and is entitled to realization, through national effort and international co-operation and in accordance with the organization and resources of each state, of the economic, social and cultural rights indispensable for his dignity and the free development of his personality. It also said in 25th article: Everyone has the right to a standard of living adequate for the health and well-being of himself and of his family, including food, clothing, housing and medical care and necessary social services, and the right to security in the event of unemployment, sickness, disability, widowhood, old age or other lack of livelihood in circumstances beyond his control. International Covenant on Economic, Social and Cultural Rights says: in accordance with the principles proclaimed in the Charter of the United Nations, recognition of the inherent dignity and of the equal and in- 
alienable rights of all members of the human family is the foundation of freedom, justice and peace in the world, Recognizing that these rights derive from the inherent dignity of the human person, Recognizing that, in accordance with the Universal Declaration of Human Rights, the ideal of free human beings enjoying freedom from fear and want can only be achieved if conditions are created whereby everyone may enjoy his economic, social and cultural rights, as well as his civil and political rights, Considering the obligation of States under the Charter of the United Nations to promote universal respect for, and observance of, human rights and freedoms, Realizing that the individual, having duties to other individuals and to the community to which he belongs, is under a responsibility to strive for the promotion and observance of the rights recognized in the present Covenant. Some scholars believe that history and reality show to us, that in the modern civilized society, it's not enough to just stay in the level of compassion, and humanitarian of social relief for families that have lost their only child group. For the group of families that have lost their only child, not only do they need to survive and development, they also need the social welfares and attention. Therefore, to set the support right of the group of families that have lost their only children in law, we are not only to improve the survival problem of them, which includes economic assistance and the perfection of spiritual solace and relevant endowment facilities, but also to rescue the future development of equal opportunity for them, to make sure childless elders have equal rights compare with other people.

\subsection{Construction of the Legal System to Protect the Rights of the Family}

Family rights are the rights based on the marital relationship, kinship, adoption, relationships or other kinship occur between relatives, including reproductive rights, the couple's status of equality rights, mutual dependency, rights to use the name, inheritance rights, adoption rights, property total rights, the right of remedies. Article 49 of our Constitution and Article 2-5, 11-48 of Marriage law have been stipulated. Compared with other rights, the most important feature of the rights to marriage and family are their physiological and biological basis. Childless elders have the right to enjoy the family. Living together with the family members is everyone's basic need, in the modern country under the rule of law, which is not only a natural human right, but also a fundamental human right guaranteed by the Constitution. UDHR of 1948 declares the rights of the family are universal human rights for the first time in the level of international law. And Article 49 of our current Constitution defines clearly that "marriage, family, mothers, children is protected by the state. The implementation of the constitutional rights of the family means that the state should not only protect the rights from private infringement, but should structure a series of legal system to protect the family rights” (Wang et al., 2013: p. 22).

\subsection{Take the Elder Care of Families That Have Lost Their Only Children into the Future Legislation}

In August 2008, the Social Relief Law (draft) has not put families that have lost their only child under social assistance. So we should respond to the following matters about families that have lost their only child in the future legislative regulations: stipulate clearly the issue about social assistance of families that have lost their only children, take them as the objectives of social assistance; specialize the provision for families that have lost their only child about standards of rescue, evaluation methods, responsibility of rescue and accountability, etc.; stipulate clearly that the goal is not just to help the group of families that have lost their only child out of the woods temporarily but to improve the practical ability; stipulate clearly that in the process of rescue we should pay attention to the participation of families that have lost their only children; stipulate clearly that we should attach great importance to the prevention rather than relief in the whole.

Meanwhile, we should attempt to introduce rules supporting fund for families that have lost their only children, so that families can enjoy the basic pension, medical insurance and social security under institutional assistance; The Law about Population and Family Planning, article 41 says that: The citizens who gave birth to children against the rules should pay social maintenance fee, and be enforced by the administrative department of family planning. Article 10 of Social Compensation Fee Collection and Management Approach says: social maintenance fee and forfeit penalty should be turned over to the state treasury, be included in local government budgets managed in accordance with the provisions of the financial department of the state, no unit or individual may withhold, embezzler, corrupt, divide. Therefore, we can take advantage of social compensation fee to set up a "special fund for childless elders", develop pension business for families that have lost their only child, protect the aged in economic interest. So we should formulate strict administrative rules governing the fund and regula- 
tory mechanisms, earmark a fund for its specified purpose only, and safeguard pension equity of families that have lost their only child really (Qi et al., 2013).

\section{Conclusion}

The issue of families that have lost their only child is not just the problem of family planning, but the civilization of a country. The problem requires the whole society's mutual care and support. But how do we help them and what kind of attitude do we hold towards them? Families that have lost their only child will affect social stability and be a measure of social civilization. Families that have lost their only child are not the inherent or special unfortunate fate in the minority but the potential risks that most families are likely to face. If our country does not address this risk with a common mechanism, then each people is likely to be painful and helpless in old age. Therefore, China should establish a completely system of family elder care for families that have lost their only child.

\section{Fund}

This article has supported by the Ministry of Education, Youth Fund Project: Study on the rights of working environment. Project number: 11YJC820171.

\section{References}

China Youth Daily (2013). Research on the Situation of Families Bereaved of Only Children: Children Elders Has Physical and Psychological Harm and Depend on Each Other on Sickbed. http://www.dayoo.com/

Liu, L. Z. (2008). Pension Rights of Citizens on the Right Attributes. Hebei Law, 56.

Liu, X. (2011). The Research of Building a Law System to Protect Vulnerable Groups. Jiangsu Social Sciences, 27-29.

Qi, E. P., \& Fu, B. (2013). Legal Analysis of Endowment Path for Childless Elders. Tianjin University of Commerce Journal, Section 5, Section 67.

Wang, Z. N., \& Wang, Q. W. (2013). Reflections on Legal Aid Mechanisms of Families Bereaved of Only Children. Pingxiang College Journal, 22.

Will, G. (2005). Traditional Social Contract Theory (pp. 389-392). Nanjing: Jiangsu People’s Publishing House.

Yang, H. W., \& Wang, W. T. (2011). The Loss and Rebuilding of Only-Children Families. Chongqing Academy of Social Sciences, 22.

Zhao, X. (2011). The Social Contract Foundation of Vulnerable Groups’ Protection. Hebei Law Science, 3. 
Scientific Research Publishing (SCIRP) is one of the largest Open Access journal publishers. It is currently publishing more than 200 open access, online, peer-reviewed journals covering a wide range of academic disciplines. SCIRP serves the worldwide academic communities and contributes to the progress and application of science with its publication.

Other selected journals from SCIRP are listed as below. Submit your manuscript to us via either submit@scirp.org or Online Submission Portal.
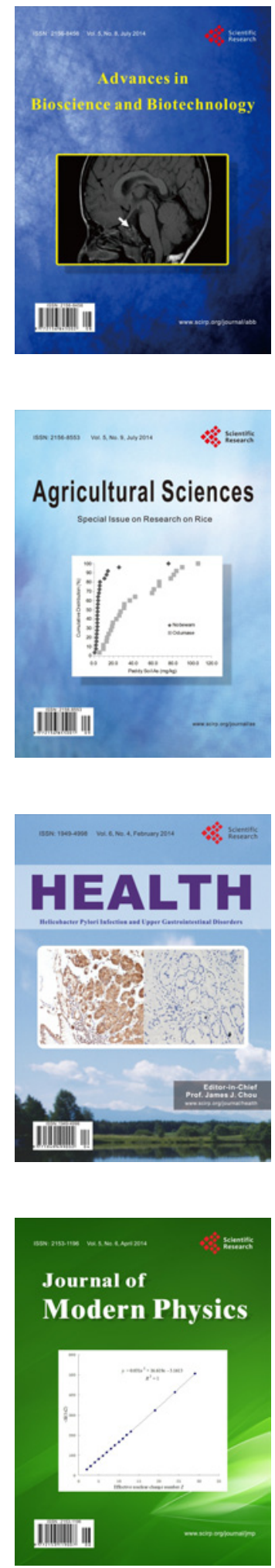
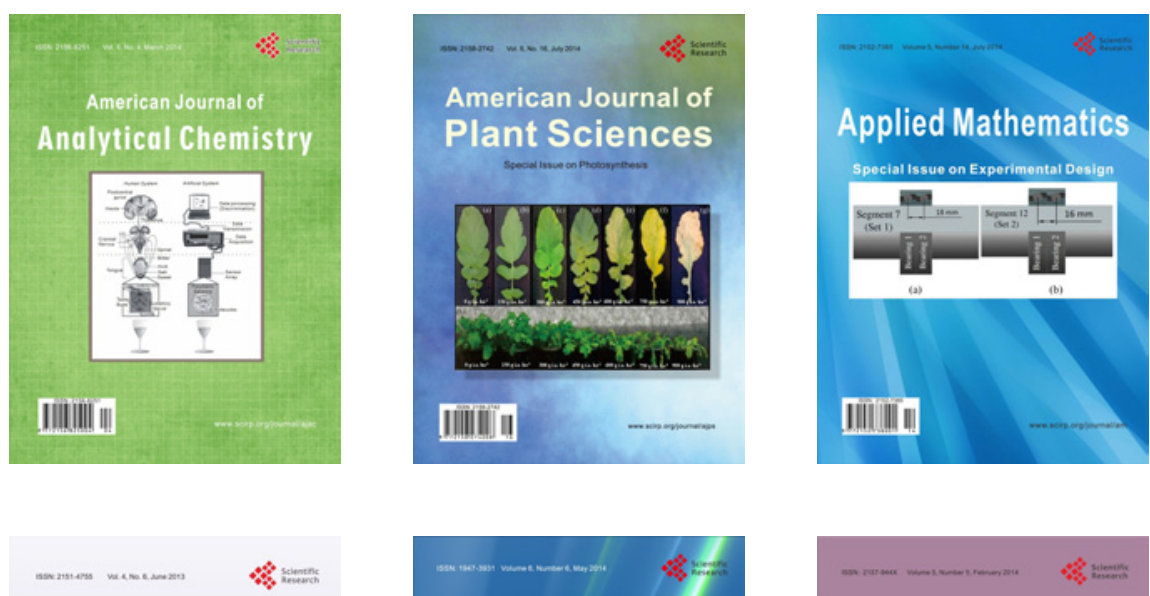

Creative Education
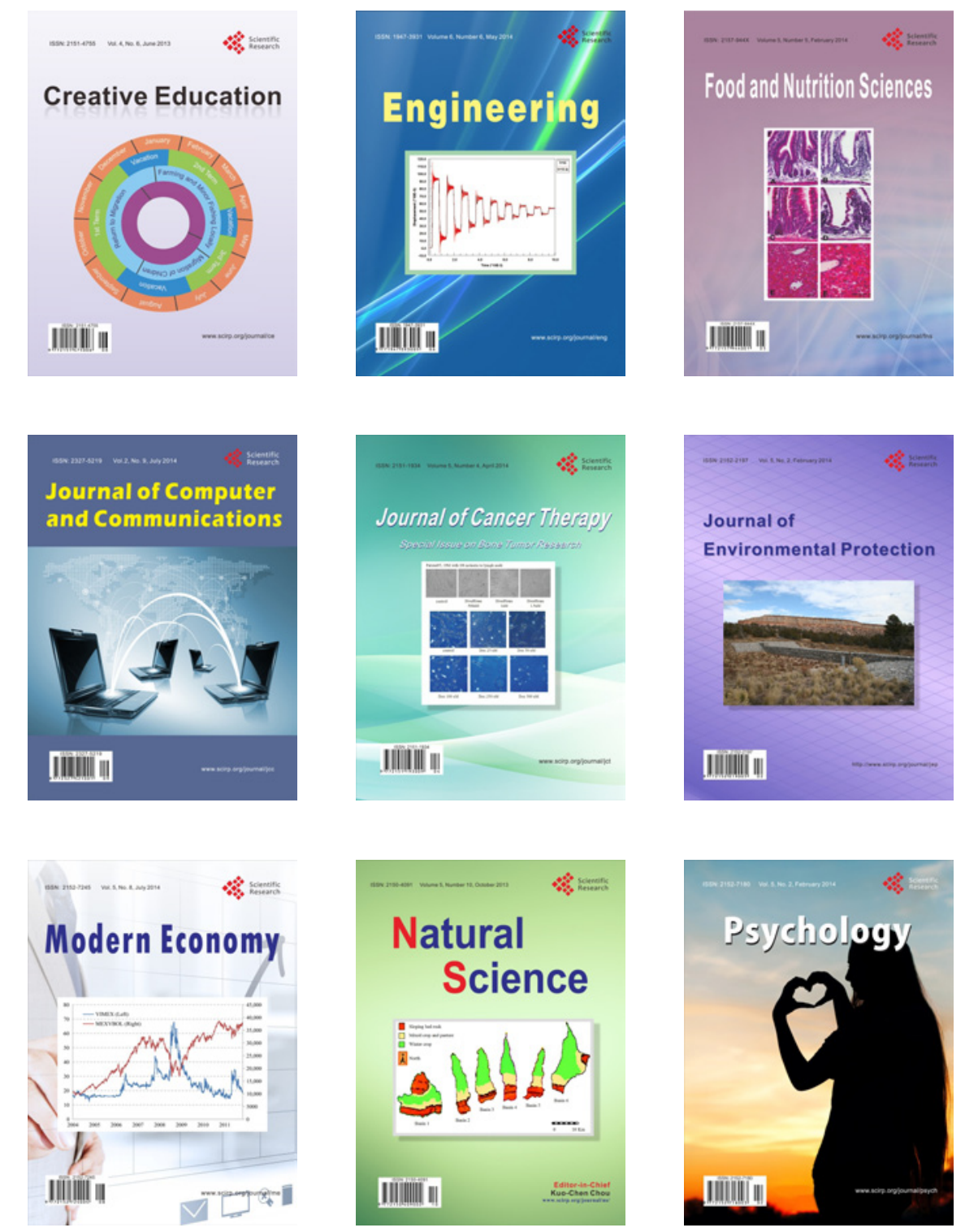